\title{
HEMAGGLUTINATION REACTION AND EPITHELIAL CELL ADHERENCE ACTIVITY OF SERRATIA MARCESCENS
}

\author{
GHAZALLY ISMAIL AND FARIDAH M. SOM \\ Faculty of Science and Natural Resources, Universiti Kebangsaan \\ Malaysia, Sabah Campus, Kota Kinabalu, \\ Sabah, Malaysia
}

(Received December 8, 1981)

\begin{abstract}
Although Serratia marcescens has been reported to possess pili, little attention has been given to the role of the pili in this organism. This piliated bacterium agglutinates human and chicken erythrocytes, and the activity is inhibited by $\alpha$-D-mannose. The degree of piliation, induced by shaking or static culture conditions, correlate with the hemagglutination activity. $S$. marcescens depiliated by UV irradiation failed to agglutinate erythrocytes. The possible role of pili as an important virulence factor in promoting adherence to host cells was studied by investigating the ability of piliated $S$. marcescens to attach to buccal epithelial cells. Results showed that $S$. marcescens attached to human buccal epithelial cells and that adherence is associated with the presence of common type-1 pili on their surfaces.
\end{abstract}

In recent years, increasing evidence has accumulated implicating adherence as an important virulence factor in various microorganism infections (1-3). The bacterial adherence to mucosal cells is thought to play a crucial role in determining the virulence of a strain during infection of the mucosal membrane. Pili of various bacteria including Neisseria gonorrhoeae $(4,5)$, Proteus hauseri (6), Salmonella (7), Escherichia coli (8) and Klebsiella pneumoniae (9), have been shown to play a role in the virulence of these organisms by promoting adhesion to host cells. The presence of surface appendages, or pili, on Serratia marcescens was first reported by Duguid and Gillies (10). Although the presence of adhesive pili and the mannose-sensitive hemagglutination activity of $S$. marcescens were previously shown by Duguid, detailed studies on the possible role of pili in promoting adherence to animal cells during infection were not made (11). This study was undertaken to establish a relationship between the presence of pili on $S$. marcescens and the latter's ability to adhere to human buccal epithelial cells. 


\section{MATERIALS AND METHODS}

Bacterial isolates. Nine clinical isolates of $S$. marcescens were obtained from patients with nosocomial infections treated at the General Hospital, Kuala Lumpur, Malaysia. The isolates were arbitrarily designated with numbers of 1 to 9 for convenience. Strains of $S$. marcescens were grown in either BrainHeart Infusion (BHI) broth medium or on BHI agar. Broth cultures were harvested by centrifugation at $3,000 \mathrm{rpm}$ for $15 \mathrm{~min}$, washed twice in phosphatebuffered saline (PBS), $\mathrm{pH} \mathrm{7.4,} \mathrm{and} \mathrm{adjusted} \mathrm{spectrophotometrically} \mathrm{to} \mathrm{the} \mathrm{desired}$ concentrations.

Radioisotope labeling of bacteria. Five $\mu \mathrm{Ci}\left[{ }^{3} \mathrm{H}\right]$-thymidine was added to $20 \mathrm{ml}$ broth cultures of $S$. marcescens followed by incubation at $37^{\circ}$ for $18 \mathrm{hr}$. Cells were harvested by centrifugation at 3,000 rpm for $15 \mathrm{~min}$ and washed three times with cold PBS, $\mathrm{pH}$ 7.4. The pellets were resuspended to the desired concentration of $10^{8}$ cells $/ \mathrm{ml}$. To determine the percentage radioactivity associated with the bacterial cells, $1-\mathrm{ml}$ samples from the ${ }^{3} \mathrm{H}$-labeled bacterial suspensions were passed through $0.45 \mu \mathrm{m}$ membrane filters, and the radioactivity associated with the filters and with the filtrates was measured.

Depiliation of bacterial cells by UV irradiation. Pili were removed from the bacterial surface by the method recently described by Silverblatt (12). Briefly, the bacterial suspension was washed three times with $0.9 \%$ sodium chloride and finally adjusted to approximately $10^{8}$ cells $/ \mathrm{ml}$ by optical density measurement. UV radiation was provided by a Mineralligh UV 254/366 N model UVSL-25 positioned approximately $3.0 \mathrm{~cm}$ above the surface of the bacterial suspension in 60-mm perti dishes, which were shaken gently. A duplicate control sample was similarly shaken but not exposed to the UV light. To minimize heating, the perti dishes were placed on ice during the irradiation and shaking. The bacterial suspensions were then harvested by centrifugation and resuspended in PBS, $\mathrm{pH}$ 7.4, before being used in the experiment.

Hemagglutination (HA) tests. The test used was a slight modification of the method described by TWEEDY and PARK (13). Briefly, blood freshly drawn from various animal species was used. Red blood cells were washed twice with normal saline and then prepared as a $1 \%(\mathrm{v} / \mathrm{v})$ suspension in PBS, pH 7.4. Each well of the hemagglutination titer plate contained $20 \mu \mathrm{l}$ of the bacterial suspension $\left(10^{8}\right.$ cells $\left./ \mathrm{ml}\right)$ and $100 \mu \mathrm{l}$ of $1 \%$ erythrocytes and was sealed with plastic film. The plates were incubated at $37^{\circ}$ for $30 \mathrm{~min}$ and then at $4^{\circ}$ for $16 \mathrm{hr}$, and examined for hemagglutination.

Tests for inhibition of HA by various sugars were done as per the HA procedure above except for using a sugar solution of a final concentration of $0.7 \%$ $(\mathrm{w} / \mathrm{v})$ as diluent.

Adherence of Serratia marcescens to human buccal epithelial cells in vitro. Buccal epithelial cell preparations were obtained as described by GiBBONS and VAN Houte (14). The ability of S. marcescens to adhere to human buccal epithelial 
cells was determined by using an in vitro system described by Gould et al. (15) with a slight modification. Labeled bacterial suspensions $\left(10^{8}\right.$ cells $\left./ \mathrm{ml}\right)$ were mixed with an equal volume $(0.4 \mathrm{ml})$ of buccal epithelial cells and shaken for $30 \mathrm{~min}$ at $37^{\circ}$. The mixtures were then centrifuged at $2,500 \mathrm{rpm}$ for $20 \mathrm{~min}$. The pellets consist of epithelial cells with adhering bacterial cells. The supernatants were discarded and the pellets washed thrice with PBS, $\mathrm{pH}$ 7.4. Finally, the pellets were resuspended and $0.2 \mathrm{ml}$ of the suspension were placed in a $10 \mathrm{ml}$ scintillation vial for the counting of buccal cell-associated radioactivity. The total radioactivity of the original bacterial suspensions was obtained from a mixture of $0.4 \mathrm{ml}$ of bacterial suspension and an equal volume of buccal epithelial cells. The adherence ratio was defined as the proportion of bacteria in the initial suspension that was recovered from the washed pellet, i.e. adherence ratio $=$ (radioactivity associated with buccal epithelial cells $[\mathrm{cpm} / \mathrm{ml}]) /($ radioactivity in incubation medium $[\mathrm{cpm} / \mathrm{ml}])$.

Electron microscopy. Cells were washed twice with $0.145 \mathrm{~m}$ sodium chloride, $\mathrm{pH} 7.0$ by centrifugation at $3,000 \times g$ for $10 \mathrm{~min}$. The pellets were resuspended and mixed with $0.016 \mathrm{M}$ ammonium molybdate. A drop of the preparation was placed on a grid covered with carbon-coated formvar and the excess removed with a filter paper point. The film was dried and the grid was examined by electron microscope.

\section{RESULTS AND DISCUSSION}

Since the colonies of $S$. marcescens have no characteristic features allowing one to selectively pick out those consisting of piliated organisms, a reliable assay to predictably screen for piliated $S$. marcescens is necessary. In $E$. coli and $N$. gonorrhoeae, the ability to hemagglutinate erythrocytes has been positively correlated with the presence of pili on the bacterial surfaces $(4,16)$. The question of whether piliated $S$. marcescens are also capable of hemagglutinating erythrocytes was asked and tested for. Nine isolates of $S$. marcescens obtained from a local hospital were examined for their hemagglutination reaction. Table 1 shows that all but one of the nine strains of BHI broth-grown S. marcescens screened for hemagglutination activity were capable of agglutinating chicken and human erythrocytes. Lower titers of HA were obtained when the erythrocytes employed in the tests were from goats or cows. Consistently good HA titers of 128, 128 and 64 were obtained with isolates of numbers 3,6 and 9, respectively (Table 1). The presence of pili on $S$. marcescens was determined by electron microscopy and all the three isolates that exhibited strong HA reaction in Table 1 were found to be heavily piliated. Figure 1 is an electron micrograph of isolate number 6 , shown as a representative observation of all the HA-positive isolates examined.

Table 2 shows that among the sugars tested, only $\alpha$-D-mannose was capable of inhibition of HA of chicken erythrocytes by $S$. marcescens grown in BHI broth. 
Table 1. Hemagglutination reactions of $S$. marcescens with erythrocytes from various animal species.

\begin{tabular}{ccccc}
\hline $\begin{array}{c}\text { S. marcescens } \\
\text { isolates } \\
\text { BHIB grown }\end{array}$ & Chicken & Goat & Cow & Human (O) \\
\cline { 2 - 5 } & 8 & $<8$ & $<8$ & $<8$ \\
1 & 16 & $<8$ & $<8$ & 32 \\
2 & 128 & $<8$ & $<8$ & 64 \\
3 & 16 & $<8$ & $<8$ & 16 \\
4 & 16 & $<8$ & $<8$ & 16 \\
5 & 128 & $<8$ & $<8$ & 64 \\
6 & 16 & $<8$ & $<8$ & $<8$ \\
7 & 8 & $<8$ & $<8$ & 8 \\
8 & 64 & $<8$ & $<8$ & 64 \\
9 & 6 & & & \\
\hline
\end{tabular}

BHIB, brain heart infusion broth.

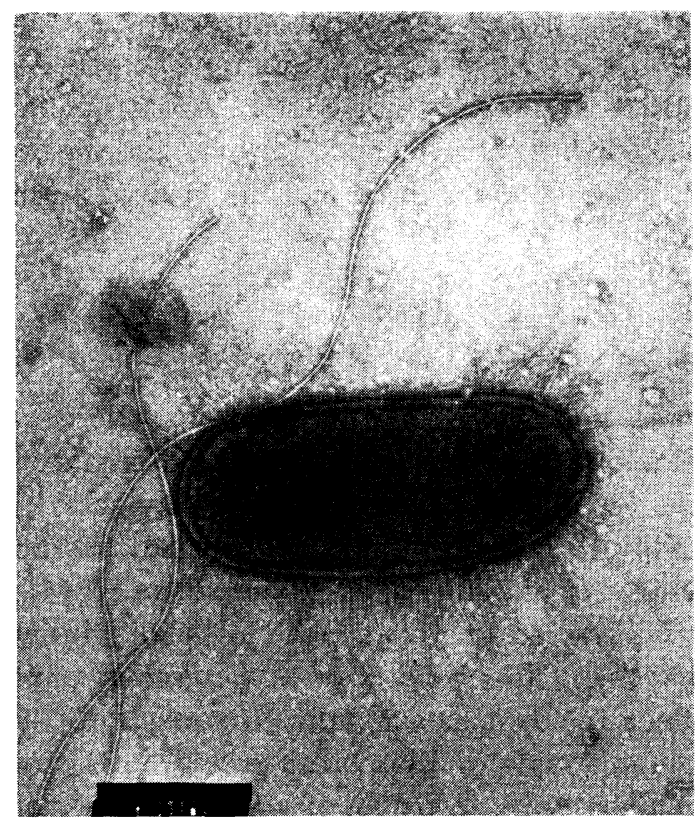

Fig. 1. Electron micrograph of negatively stained Serratia marcescens isolate 6 showing piliation of the surface. Magnification, $\times 65,000$.

In E. coli, Salmonella and Shigella, the presence of common type 1 pili on their surfaces confers on them the ability to agglutinate erythrocytes, the process being reversed by low concentrations of $\alpha$-D-mannose $(17,18)$. In contrast, the presence of colonization factor antigen in $E$. coli confers on these bacteria an HA activity which is not reversed by $\alpha$-D-mannose (19). With $S$. marcescens, results indicated that the HA activity is mannose-inhibitable, suggesting that the HA 
Table 2. Inhibition of hemagglutination reactions of chicken erythrocytes by various sugars.

\begin{tabular}{cccccccccc}
\hline $\begin{array}{c}\text { S. marcescens } \\
\text { isolates }\end{array}$ & Man & Fruc & Mann & Inu & Gal & Lac & Sor & Glu & Mal \\
\hline 1 & + & - & - & - & - & - & - & - & - \\
2 & + & - & - & - & - & - & - & - & - \\
3 & + & - & - & - & - & - & - & - & - \\
4 & + & - & - & - & - & - & - & - & - \\
5 & + & - & - & - & - & - & - & - & - \\
6 & + & - & - & - & - & - & - & - & - \\
7 & + & - & - & - & - & - & - & - & - \\
8 & + & - & - & - & - & - & - & - & - \\
9 & + & - & - & - & - & - & - & - & - \\
\hline
\end{tabular}

Man, mannose; Fruc, fructose; Mann, mannan; Gal, galactose; Lac, lactose; Sor, sorbitol; Gluc, glucose; Mal, maltose.

Table 3. Hemagglutination reactions of chicken erythrocytes caused by

$S$. marcescens obtained from different growth culture conditions.

\begin{tabular}{cccc}
$\begin{array}{c}S . \begin{array}{c}\text { marcescens } \\
\text { isolates }\end{array} \\
\text { BHIB shaking }\end{array}$ & BHIB static & BHIA \\
\hline 1 & $<8$ & 16 & 16 \\
2 & 8 & 16 & 16 \\
3 & 64 & 128 & 32 \\
4 & 8 & 32 & 16 \\
5 & 16 & 32 & $<8$ \\
6 & 64 & 356 & $<8$ \\
7 & $<8$ & 8 & 8 \\
8 & $<8$ & 16 & 16 \\
9 & 64 & 126 & 32 \\
\hline
\end{tabular}

Expressed as inverse of dilution of standardized bacterial suspension causing hemagglutination.

BHIB, brain heart infusion broth; BHIA, brain heart infusion agar.

reaction observed was mediated by the presence of common type 1 pili.

The degree of piliation of $S$. marcescens and its ability to agglutinate erythrocytes was also studied. The growth conditions of the bacterial culture have been shown to alter the number of pili on bacterial surfaces; for instance, organisms grown in broth cultures in shaken flasks possess fewer pili on their surfaces than those obtained from broth culture $(7,20)$. Table 3 shows that when $S$. marcescens strains were grown under constant shaking in BHI broth medium or on agar plates, HA titers were found to be lower for all isolates tested when compared to those gorwn in BHI broth medium under stationary conditions. Depiliation of these organisms by UV irradiation also decreased the HA activity (Table 4). Thus, there appears to be a correlation between the degree of piliation and the HA activity of $S$. marcescens. 
Table 4. Hemagglutination reactions caused by $S$. marcescens UV-irradiated prior to incubation with chicken erythrocytes.

\begin{tabular}{cccc}
\hline \begin{tabular}{c} 
S. $\begin{array}{c}\text { marcescens } \\
\text { isolates }\end{array}$ \\
\cline { 2 - 4 }
\end{tabular} & Not irradiated & UV 30 min & UV 60 min \\
\hline 1 & 16 & $<8$ & $<8$ \\
2 & 16 & 16 & $<8$ \\
3 & 126 & 16 & $<8$ \\
4 & 32 & 8 & $<8$ \\
5 & 32 & 16 & 8 \\
6 & 356 & 8 & 8 \\
7 & 16 & $<8$ & $<8$ \\
8 & 16 & $<8$ & $<8$ \\
9 & 126 & 8 & $<8$ \\
\hline
\end{tabular}

Table 5. Adherence activity of $S$. marcescens with human buccal epithelial cells.

\begin{tabular}{|c|c|c|c|c|}
\hline \multirow[b]{2}{*}{$\begin{array}{l}\text { S. marcescens } \\
\text { isolates }\end{array}$} & \multicolumn{4}{|c|}{ Radioactivity (cpm) } \\
\hline & $\begin{array}{l}\text { In incubation } \\
\text { medium alone }\end{array}$ & $\begin{array}{l}\text { With buccal } \\
\text { epithelial cell }\end{array}$ & $\begin{array}{l}\text { With buccal } \\
\text { epithelial cell } \\
+ \\
0.7 \% \text { mannose }\end{array}$ & $\begin{array}{l}\text { Adherence } \\
\text { ratio }\end{array}$ \\
\hline \multirow[t]{2}{*}{3} & 860 & 566 & - & 0.65 \\
\hline & 923 & - & 88 & 0.09 \\
\hline \multirow[t]{2}{*}{6} & 820 & 492 & - & 0.60 \\
\hline & 903 & - & 72 & 0.08 \\
\hline \multirow[t]{2}{*}{9} & 890 & 608 & - & 0.68 \\
\hline & 863 & - & 68 & 0.08 \\
\hline
\end{tabular}

To evaluate the role of pili in promoting adherence to host cells, the ability of piliated $S$. marcescens to attach to buccal epithelial cells was determined. The quantitation of adherence activity was done by incubating epithelial cells with isotopically labelled $S$. marcescens. The use of radioactively labelled $S$. marcescens eliminated the problems associated with identifying or removing indigenous bacteria that frequently colonize epithelial cells. Table 5 shows the results of adherence activity for three isolates which were previously shown to possess high HA titers. It was found that piliated strains $S$. marcescens attached to human buccal epithelial cells and that adherence can be completely inhibited by $\alpha$-D-mannose (Table 5) suggesting that mannose-containing receptors similar to those involved in the HA reaction are also important in the epithelial cell adherence activity.

UV irradiation of the bacteria prior to incubation with the epithelial cells resulted in the reduction of adherence activity of $S$. marcescens (Table 6). Furthermore, bacteria grown in static broth for $72 \mathrm{hr}$ to stimulate pili formation adhered much more avidly than organisms grown in a shaken broth medium or on agar, conditions not conducive to piliation (Table 7). UV irradiation also 
Table 6. Effects of UV irradiation on hemagglutination reactions and epithelial cell adherence activity of $S$. marcescens.

\begin{tabular}{|c|c|c|c|c|c|c|}
\hline \multirow{2}{*}{$\begin{array}{l}\text { S. marcescens } \\
\text { isolates }\end{array}$} & \multicolumn{2}{|c|}{ Control } & \multicolumn{2}{|c|}{ UV $30 \mathrm{~min}$} & \multicolumn{2}{|c|}{ UV $60 \mathrm{~min}$} \\
\hline & HA titer & $\begin{array}{l}\text { Adehrence } \\
\text { ratio }\end{array}$ & HA titer & $\begin{array}{l}\text { Adherence } \\
\text { ratio }\end{array}$ & HA titer & $\begin{array}{l}\text { Adherence } \\
\text { ratio }\end{array}$ \\
\hline 3 & 126 & 0.58 & 16 & 0.27 & $<8$ & 0.24 \\
\hline 6 & 356 & 0.47 & 8 & 0.17 & 8 & 0.21 \\
\hline 9 & 126 & 0.63 & 8 & 0.24 & $<8$ & 0.27 \\
\hline
\end{tabular}

Table 7. Effects of culture-growth conditions on epithelial cell adherence activity of $S$. marcescens.

\begin{tabular}{cccc}
\hline \multirow{2}{*}{$\begin{array}{c}\text { marcescens } \\
\text { isolates }\end{array}$} & \multicolumn{3}{c}{ Adherence ratio } \\
\cline { 2 - 4 } & Static broth culture & Shaken broth culture & Agar plates \\
\hline 3 & 0.62 & 0.34 & 0.29 \\
6 & 0.60 & 0.41 & 0.37 \\
9 & 0.67 & 0.45 & 0.36 \\
\hline
\end{tabular}

reduced the HA activity of each of the $S$. marcescens isolates tested. In general, the reduction in adherence ratios paralleled the decrease in HA titers exhibited by the 3 isolates examined.

Our present investigation thus suggests that hemagglutination ability and adherence to epithelial cells by $S$. marcescens is associated with the presence of common type 1 pili on its surface. These pili may contribute to the virulence of $S$. marcescens by conferring on the organism the capacity to adhere to epithelial cells, which is thought to be a prerequisite for some bacterial pathogens to establish infections at the sites of colonization.

\section{REFERENCES}

1) H. Sмith, Bacteriol. Rev., 41, 475 (1977).

2) R. J.Gibbons and J. van Houte, Annu. Rev. Microbiol., 29, 19-44 (1975).

3) P. A. MARdh and L. Westrom, Infect. Immun., 13, 661 (1976).

4) A. P. Punsalang, Jr. and W. D. Sawyer, Infect. Immun., 8, 255 (1973).

5) I. Ofek, E. H. BeAchy, and A. L. Bisno, J. Infect. Dis., 129, 310 (1974).

6) W. L. H. Shedden, J. Gen. Microbiol., 28, 1 (1962).

7) D. C. Old, I. Cornell, L. F. Gibson, A. D. Thompson, and J. P. Duguid, J. Gen. Microbiol., 51, 1 (1969).

8) C. F. Deneke, G. M. Thorne, and S. L. Gorbach, Infect. Immun., 26, 362 (1979).

9) R. C. Fader, A. E. Avots-Avotins, and C. P. Davis, Infect. Immun., 25, 729 (1979).

10) J. P. Duguid and R. R. Gillies, J. Pathol. Bacteriol., 75, 519 (1958).

11) J. P. Duguid, J. Gen. Microbiol., 21, 271 (1959).

12) F. J. Silverblatt, Infect. Immun., 25, 1060 (1979).

13) J. M. TWeedy and R. W. A. PARK, J. Gen. Microbiol., 51, 235 (1968).

14) R. J. Gibbons and J. van Houte, Infect. Immun., 3, 567 (1971). 
15) K. Gould, K. H. Ramirez-Rouda, R. K. Holmes, and J. P. Sanford, J. Clin. Invest., 56, 1364 (1975).

16) J. P. Duguid and R. R. Gillies, J. Pathol. Bacteriol., 75, 335 (1958).

17) J. P. Duguid and R. R. Gillies, J. Pathol. Bacteriol., 74, 397 (1957).

18) M. Hashimoto, S. Tsuchimoto, A. Kato, T. Takemoto, T. Yoshino, M. Ikuta, and M. Nakajima, Bull. Tokyo Med. Dent. Univ., 10, 181 (1963).

19) D. G. Evans, D. J. Evans, Jr., and W. Tuoa, Infect. Immun., 18, 330 (1977).

20) H. S. Arai and J. H. Munoz, Infect. Immun., 25, 764 (1979). 